\title{
Abundant herds: Accumulation, herd management, and land-use patterns in a conservation area
}

\author{
Michael Bollig ${ }^{*^{*}}$ a and Hauke-Peter Vehrs ${ }^{2}$
}

\begin{abstract}
North-eastern Namibia's Zambezi Region became part of the world's largest transboundary conservation area in the early 2010s: the Kavango-Zambezi Transfrontier Conservation Area. While wildlife numbers and wildlife-based tourism are increasing rapidly in this conservation zone, cattle herds and livestock-based economies are expanding as well. More than conservation and wildlife-based tourism, cattle husbandry is a project of the local population and of the local elite in particular. Cattle are an expression of wealth and are regarded as a means of saving. At the same time, cattle can be used to plough fields, pull sledges, and produce milk and meat for home consumption and also for sale. Cattle also fulfil important social functions; they are necessary for bridewealth payments and are used in cattle loans with which wealthy herd owners furnish poorer relatives. Recent investments into self-financed boreholes have opened new rangelands for the wealthy, while the expansion of conservation areas in the region's wetlands and the establishment of wildlife corridors have rendered other rangelands challenging due to prohibitions and increasing incidences of human-wildlife conflict. The needs and practices of expanding cattle husbandry often conflict with the demands and challenges of conservation and conservation-related tourism. This contribution describes the emergence and expansion of cattle husbandry in a region which had hardly any cattle before the 1960s and which has seen a major expansion of conservation areas and a subsequent refaunation since the 1980s. The contribution analyses current cattle ownership patterns and management practices. We argue that livestock husbandry and conservation have to be considered together and not as competing land-use strategies that need to be kept apart but as separate visions and aspirations of different stakeholders relating to the same landscape.
\end{abstract}

Keywords: Conservation, Cattle husbandry, Wealth accumulation, Human-wildlife conflict, Zambezi Region, Namibia

\section{Introduction}

Since 2011, the Kwando River wetlands and the adjoining tree savannahs in Namibia's Zambezi Region have formed part of the huge Kavango Zambezi Transfrontier Conservation Area. Its community-based conservancies and its three national parks (Mudumu, Nkasa Rupara, and Bwabwata) contribute significantly to the world's

\footnotetext{
* Correspondence: michael.bollig@uni-koeln.de

'Institute for Social and Cultural Anthropology, University of Cologne, Cologne, Germany

Full list of author information is available at the end of the article
}

largest transboundary conservation area. The conservation landscape is established by a mosaic of areas exclusively used by wildlife (and tourism) and administered by government offices, game corridors and core conservation areas. These areas are co-managed by conservancies, non-governmental organisations and administration and multi-use areas used by agro-pastoralists under the leadership of traditional authorities. Social scientists and ecologists alike have reflected upon the social, cultural, and economic impact of conservation. Ecologists have frequently focused on the increase in wildlife numbers,

\section{Springer Open}

(c) The Author(s). 2020 Open Access This article is licensed under a Creative Commons Attribution 4.0 International License, which permits use, sharing, adaptation, distribution and reproduction in any medium or format, as long as you give appropriate credit to the original author(s) and the source, provide a link to the Creative Commons licence, and indicate if changes were made. The images or other third party material in this article are included in the article's Creative Commons licence, unless indicated otherwise in a credit line to the material. If material is not included in the article's Creative Commons licence and your intended use is not permitted by statutory regulation or exceeds the permitted use, you will need to obtain permission directly from the copyright holder. To view a copy of this licence, visit http://creativecommons.org/licenses/by/4.0/. 
diverse mobility patterns, and human-wildlife conflict (e.g. Naidoo et al. 2012, 2016a, 2018; Stoldt et al. 2020). Economists have elucidated to what extent income from conservation complements the diversification of rural livelihoods (Naidoo et al. 2016b, Kalvelage et al. n.d.). Social scientists and historians have displayed the colonial roots of conservation; highlighted the relation between colonial violence and conservation (Lenggenhager 2018) (Bollig \& Vehrs (n.d.): The making of a conservation landscape: The emergence of a conservationist environmental infrastructure along the Kwando River in Namibia's Zambezi Region, Africa. forthcoming); analysed the effects of community-based conservation on social institutions (Silva and Mosimane 2014), and critiqued elite capture of gains from conservation (Lubilo 2018), the marginalization of e.g. forager communities (Taylor 2012), and the discursive formation of conservation (Moore 2010). The near-complete focus of social scientists, economists, and ecologists on conservation and wildlife has hidden the fact that agricultural and pastoral strategies are still of significant importance to Zambezi's rural population and that conservation efforts and agro-pastoralism are tightly interlocked. Not only were essential parts of rural livelihoods not considered in any empirical detail, but key drivers of environmental change also remained unexplained, and crucial dynamics of societal differentiation were under-researched.

This paper sketches the development of cattle husbandry in and close to lands that were designated as conservation areas since the 1980s. It scrutinizes livestock-related practices within a framework set by the emergence of three national parks that inhibit pastoral use of rangelands within the parks' lands and a number of community-based conservation areas that stipulate wildlife corridors and conservation zones.

The expansion of cattle husbandry and the establishment of conservation areas took place in a period of political troubles and violent conflict. Throughout the 1980s, the South African army was very present in the area and a lot of poaching that took place during that period was connected to illegal hunting by soldiers and administrative staff (Lenggenhager 2018). The first decade after independence saw conflicts between the state and a separatist movement which worked for the autonomy of the region. Conflict and violence could not preclude the emergence of an elite though. Connected to labour migration to South Africa in the 1950s and the 1960s, the expansion of the administration in the Caprivi linked to the build-up of a Bantustan Administration for the East Caprivi in the 1970s and 1980s (Kangumu 2011:111-126) and the progressive integration of people with higher formal education from the region as high-ranking civil servants into state bureaucracy, capital entered the region and sought for culturally appropriate ways of investment since the 1990s.
We start from the observation that while wildlife numbers have indeed recovered remarkably over the past two decades (Stoldt et al. 2020: Supplement $6^{1}$ ); the animal species that multiplied most rapidly were cattle. It is specifically in the buffer zones around national parks in the conservancies that both wildlife and cattle feed on the same resources. It is in these conservancies that different development strategies conflict and that communitybased conservation efforts and cattle husbandry overlap. The establishment of two national parks (Nkasa Rupara and Mudumu) narrowed down spatial strategies of cattle owners as the wetlands of the region became less accessible, and where they were accessible, they became more dangerous due to increasing numbers of predators. The recent planning for wildlife corridors that connect conservation areas increases the chance of problematic humancattle-wildlife interactions.

But why more cattle in a region where conservation and tourism are flourishing? While wealthy people certainly benefitted from community-based conservation and perhaps also did so disproportionately, the major venue of accumulation was cattle husbandry and not wildlife-based tourism. Wealthy farmers bought cattle, drilled boreholes, and combined large herds of cattle with large agricultural fields in lands that had been agriculturally underutilized-but they rarely invested into touristic infrastructure. But less wealthy households also invested in cattle, buying one or two heads themselves, and borrowing some more from well-off relatives, many with the aim of having a sufficient number of oxen to pull a plough. In a very obvious way, wealth is connected to cattle ownership, and poverty to the absence of cattle.

There is an obvious impasse between increasing cattle numbers and elite strategies to invest in cattle herds and large farmsteads on the one hand, and growing wildlife numbers and a focus on conservation on the other. Many planners and certainly many advocates of conservation regard these two trends as incompatible. ${ }^{2}$ This scenario suggests four key questions for this contribution: (1) How did

\footnotetext{
${ }^{1}$ Stoldt et al. (2020) give a detailed account of wildlife dynamics in the Zambezi Region. It is particularly elephant numbers which have increased significantly from about 4500 to about 8000 animals since the 1990s. Lechwe, redbuck, and wildebeest numbers have increased as well although it is more difficult to give exact numbers. Also, carnivore numbers have increased according to Stoldt et al. 2020.

${ }^{2}$ The Ministry of Lands and Resettlement (2015a) advocates a conservative approach to cattle husbandry and argues that by 2025 , livestock diseases should be under control by improving veterinary services, cattle husbandry should be further commercialized, and access to markets should be granted. The land-use plan argues that 'there is conflict between this sector (i.e. cattle husbandry) and wildlife' and refers to frequent depredation of cattle by carnivores and the regular infection of cattle by the foot and mouth disease-causing virus hosted by growing herds of buffalo. The report argues for the establishment of a zone of commercial ranching of 150,000 ha separate from the conservation landscape (see Fig. 1).
} 


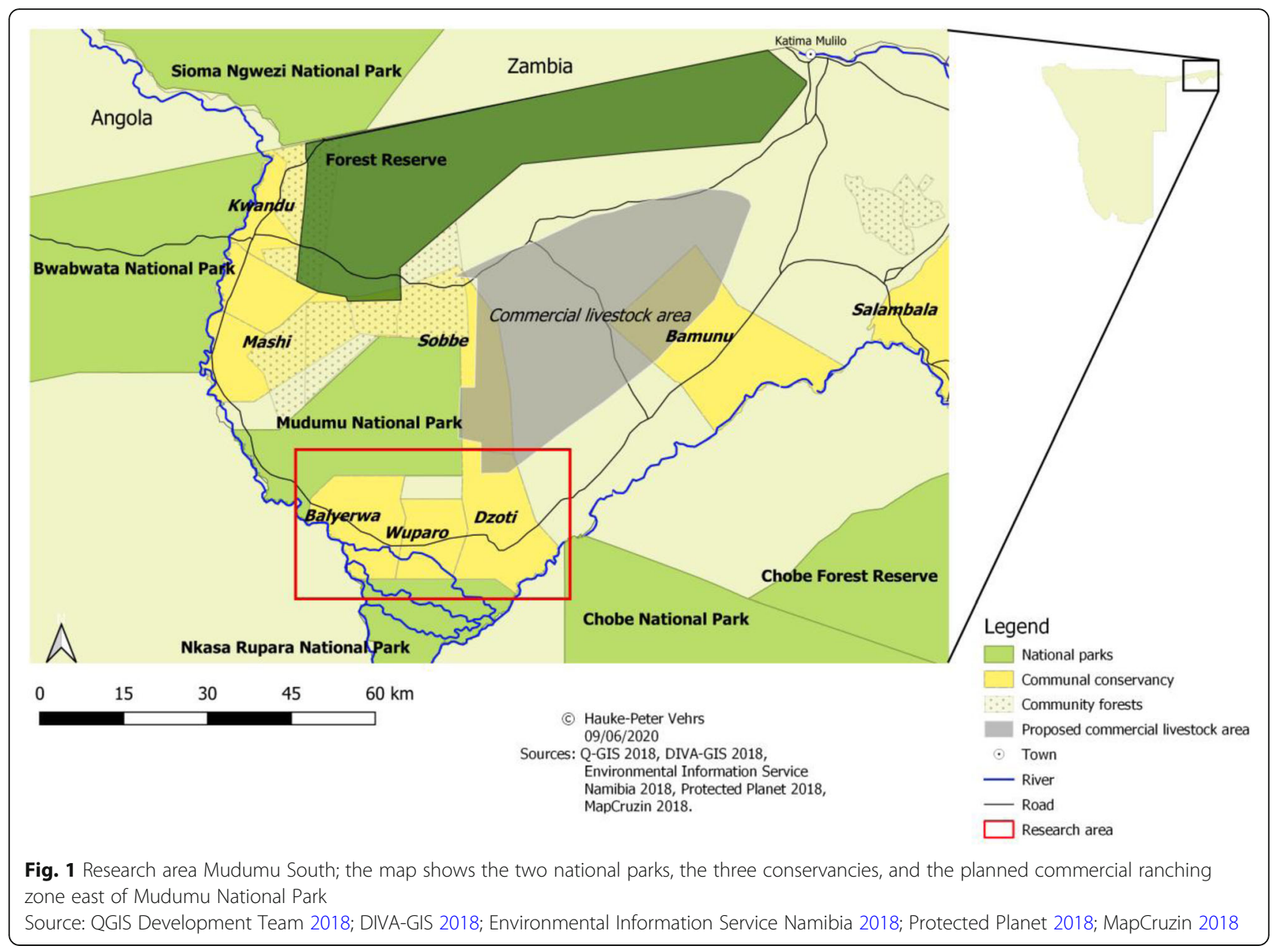

cattle husbandry unfold in an area which had hardly any livestock at the beginning of the twentieth century, and to what extend was it an expression of increasing inequalities in a rural population? (2) What are the organizational patterns of different forms of cattle husbandry? (3) How are cattle being put to use, and how are cattle invested in other commodities, in social links and assets by owners of different wealth and different access to pastures? (4) How do increasing numbers of cattle and wildlife interact? ${ }^{3}$

This contribution focusses on cattle husbandry in Mudumu South, an area of c. $660 \mathrm{~km}^{2}$ of wetlands and open tree savannah, nowadays occupied by c. 4600 people (NACSO, website). The term Mudumu South is borrowed from conservationist literature and describes lands hemmed in between two national parks (Mudumu and Nkasa Rupara). These lands are occupied by three communitybased conservation areas (the conservancies Balyerwa, Wuparo, and Dzoti) (see Fig. 1). Conservancies were founded after an overhaul of legislation on nature

\footnotetext{
${ }^{3}$ We exclude the question of how increasing cattle herds do contribute to changing environmental infrastructures in this article and intend to address this issue in a further contribution.
}

conservation in the mid-1990s. The government cedes certain rights over space and wildlife to communities and gazettes these spaces as conservancies on the basis of provisions that communities (a) define territorial boundaries, community membership, and land-use patterns in a concise manner, leaving ample space for core conservation areas and game corridors spared from human use, and (b) establish elected committees as governance bodies and establish transparent ways of handling funds, contracts, and partnerships. Once gazetted, conservancies are entitled to rent out land to lodges and campsites run by private entrepreneurs and to sell a wildlife quota assigned to them by the Ministry of Environment, Forestry and Tourism to commercial trophy hunters. The profits accruing from such public-private partnerships belong to the conservancy, and a conservancy committee may decide how to disburse such funds. While conservancies establish a new form of land governance, the three conservancies of Mudumu South are part of the territory of the Mayeyi chiefdom, with the chief and the main traditional court (khuta) residing in Sangwali, the only larger settlement in the area, and sub-khutas in neighbouring villages (Lubilo 2018). Today, about 5000 cattle are kept in Mudumu South. They are herded in the 
open tree savannah and in the wetlands along the Kwando River and its inundation areas. However, large parts of the wetland areas are nowadays under a conservation regime excluding alternative land uses and necessitating the opening up of new lands for permanent pastoral use and the move of large cattle herds into the tree savannah. Our contribution relates the history of cattle keeping in the region, shows patterns of current livestock ownership, describes mobility and settlement strategies, depicts the drivers of livestock accumulation, and discusses the intersection of wildlife-based and livestock-based economies.

\section{The slow emergence of cattle herding during colonial times}

Early colonial travellers and administrators took a keen interest in cattle numbers in the areas they travelled. Large cattle herds gave evidence of the wealth of a region and opened avenues for long-distance trade and taxation. The Caprivi region (by and large today's Zambezi Region) was very disappointing in this respect. The Austrian geographer Seiner travelled the region in 1906. He remarked that the expansion of the tsetse flies and with it the dreaded cattle disease trypanosomiasis (locally named nagana) and the great Rinderpest panzoetic had reduced cattle numbers severely (Seiner 1909a:9, b). According to Seiner, cattle were extremely rare in the Caprivi in the early 1900s (see also Streitwolf 1911:130). While the Kwando/Linyanti basin was used seasonally by Barotse nobles to keep a sizeable cattle herd of about 20,000 animals there (Seiner 1909a:11), these herds were repatriated to lands north of the Zambezi River (Seiner 1909b:35) when the British Government closed the Zambezi border against cattle imports into Northern Rhodesia in 1906. Seiner reports that during his travels through the lands of the Mafwe and Mayeyi in the western parts of today's Zambezi Region, he found just one cow in the possession of a local Mafwe headman (Seiner 1909b:102) and some more in Mayuni village at the Kwando River. Despite the fact that there were hardly any cattle to be found in the region, Seiner described the Caprivi landscape as a favourable ranching zone apt for commercial livestock farming (Seiner 1909a:51), an idea taken up in a number of planning documents since then.

Seiner (1909a) also gives an idea how land tenure was organized after the predominance of Barotse rulers had been broken by emergent colonial administrations. Before this time, the Barotse had installed headmen who controlled land and taxed homesteads organized in small kinship ${ }^{4}$ based villages. Villages were relocated frequently when soils got exhausted. Many localized kin groups established a

\footnotetext{
${ }^{4}$ There are diverging accounts on kinship reckoning. While Pretorius (1975:55) claims that matrilineal social organization dominates, Kangumu (2011:26) establishes that kinship is 'established bilaterally, with relatives traced as widely as possible through both consanguineal and affinal ties'.
}

rainy season village inland in the dry tree savannah and a dry season village in or at the wetlands of the Kwando. Under German and then South African rule, a chiefly system got firmly established. ${ }^{5}$ The Mafwe chief, resident at Chinchimani, had councils established in each village including in those villages dominated by Mayeyi and Hambukushu peoples. Village councils (khuta) controlled tenure arrangements and handled conflicts over land (Pretorius 1975:72-81). In recent years, land tenure has been formalized. The communal land reform of 2003 stipulated the establishment of land boards, consisting of government officers and representatives of NGOs and traditional authorities. Chiefs and their councils, land board, and officials of the Ministry of Lands and Resettlement campaigned for the formal registration of traditional land rights. Each land user was entitled to register parcels of land and got them surveyed and catalogued. In Mudumu South, a great number of people got their rights to parcels of land registered in the 2010s. Especially wealthy people sought for the registration of parcels of land.

Back to the cattle: In the 1920s and 1930s cattle numbers picked up gradually and in 1940 the number of cattle in the entire region was estimated to be around 23, $000 .{ }^{6}$ In 1950, the numbers had increased somewhat to 26,000 but in 1954 declined again to 24,000 . Another tsetse epidemic diminished cattle numbers throughout the 1950s, and by 1959, only 9000 cattle were living in the entire East Caprivi Region. ${ }^{7}$

During the first decades of colonial penetration and the establishment of colonial administration, cattle husbandry did not feature importantly in the socialecological system. There is certainly no long-term coevolution of grasslands and large herds of domesticated herbivores as in other regions of south-western Africa (Bollig 2020) or eastern Africa (Lane 2013).

\footnotetext{
${ }^{5}$ The Republic of South Africa had been mandated to administer the former German colony South West Africa in 1920. By virtue of this mandate, also north-eastern Namibia, habitually dubbed the Caprivi Strip, came under South African control. However, the region was administered by British Bechuanaland from 1920 to 1929, then from Windhoek from 1929 to 1939 and after that-unlike the remainder of Namibia-directly from Pretoria until 1971 when the East Caprivi became a pseudo-independent homeland (Lenggenhager 2018).

${ }^{6}$ NAN KCA 6 N_15_6. Caprivi von Bantoesakecommissaris Katima Mulio an Sekretaris Bantoe-Administrasie en Ontwikkeling 2/10/1961. The numbers are estimates by colonial officials who visited rural villages. They did not count livestock but estimated numbers. They also corroborated their estimates with accounts by local traditional authorities who were habitually questioned on livestock numbers. Vaccinations became regular annual events in the mid-1960s. From then on, figures are based on counts.

${ }^{7}$ NAN KCA 6 N_15_6. Bantoesakecommissaris Katima Mulio an Sekretaris Bantoe-Administrasie en Ontwikkeling 2/10/1961.
} 
Cattle numbers increased substantially since the 1960s and were moved to the centre stage of colonial development planning in subsequent years. In 1964, the Odendaal Report, ${ }^{8}$ the blueprint for the development of the South African-dominated Bantustans, stipulated that 'The cattle population could be greatly improved through the use of better bulls and the effective control of diseases'. The report encouraged the local administration to invest in the build-up of commercially oriented cattle production. Dreams about a flourishing cattle industry, which had been already part and parcel of Seiner's development ideas for this stretch of land, resurfaced. In subsequent years, the administration was determined to increase cattle holdings. Tsetse infestation was held to be the primary hindrance for any substantial further increase in cattle numbers. In 1965, for the first time, the highly poisonous organochloride dieldrin (Dieldrex) was sprayed on the ground in bush-encroached areas in the wetlands in order to directly attack Glossina morsitans, the transmitter of trypanosomes (Bollig \& Vehrs (n.d.): The making of a conservation landscape: The emergence of a conservationist environmental infrastructure along the Kwando River in Namibia's Zambezi Region, Africa. forthcoming). ${ }^{9}$ Besides the spraying of riverine bushlands, cattle were vaccinated with the drug Berenil ${ }^{10}$ in order to prevent them from getting sick with nagana (bovine sleeping sickness). ${ }^{11}$ While in the 1960s, spraying was mainly done by teams of sprayers fitted with knapsack equipment, since the 1970s, spraying of the Kwando basin on the Botswanan as well as the South African/Namibian side with organochloridebased insecticides (first Dieldrin, later Endosulphan) was done from low-flying planes, while on-the-spot spraying of Glossina breeding grounds in the Kwando wetlands continued (Kurugundla et al. 2012) (Bollig \& Vehrs (n.d.): The making of a conservation landscape: The emergence of a conservationist environmental infrastructure along the Kwando River in Namibia's Zambezi Region, Africa.

\footnotetext{
${ }^{8}$ NAN OCO Secretary of the South West Africa Commission 1963 (Odendaal Commission), on microfilm (AMR 0022-0029). p. 293. Accessioned as A.0794. The original is in the National Archives of South Africa, Pretoria, here page 423.

${ }^{9}$ While the East Caprivi administration adopted similar strategies as the Botswana administration (see Morton 1996, Bolaane 2013), the culling of wildlife and the establishment of wildlife fences to prevent the infiltration of game as a potential host to trypanosomes were not adopted in the East Caprivi (Bollig \& Vehrs (n.d.): The making of a conservation landscape: The emergence of a conservationist environmental infrastructure along the Kwando River in Namibia's Zambezi Region, Africa. forthcoming)

${ }^{10}$ Introduced to the market as a trypanocide for domestic livestock in 1955, its use rapidly spread in Africa. In Kenya, for example, the doses administered to cattle rose from 2000 in 1957 to 190,000 (!) in 1961 (Peregrine and Mamman 1993:183).

${ }^{11}$ NAN KCA 6 N_15_6, Zustandsbericht Caprivi von Bantoesakecommissaris Katima Mulio and Sekretaris BantoeAdministrasie en Ontwikkeling 2/10/1961.
}

forthcoming). By the early 1970s, trypanosomiasis was no longer a serious impediment to cattle husbandry.

A number of other programmes contributed to the increase of cattle in the region. A yearly 'crusade to improve cattle' (Veeverbeteringsveldtog) aimed to identify and then castrate young bulls of lower quality. ${ }^{12}$ The report for 1972, for example, lists a number of cattle in different villages under the entry: "The following cows and heifers were eliminated due to old age, infertility and weak constitution.' ${ }^{13}$ Another entry listed under 'The following young bulls were castrated' gives the number of castrated male animals in each village. Officials also directly intervened in livestock management practices. Local herders occasionally pierced the nose of a calf with a stick in order to wean it. The stick prevented the calf from going for the teats of the mother cow. This practice was prohibited and became a punishable offence in the 1970s. ${ }^{14}$ A number of newly drilled boreholes extended the grazing range of cattle herds. In 1972, some 67 wells had been drilled and equipped all over the East Caprivi.

With the application of modern insecticides and vaccines and new income from working as migrant labour, cattle herds increased steadily. In the mid-1980s, cattle numbers had risen to more than 50,000, and in 1993, for the first time, more than 100,000 cattle were counted in the Caprivi. The rapid and unprecedented increase in cattle was much commented upon in the 1990s, and attention was drawn to the vast consequences of this trend (Mendelsohn and Roberts 1997:30). ${ }^{15}$ Better conditions for cattle husbandry resulted in larger numbers of households owning cattle, increased consumption levels of cattle owners, increasing availability of draught oxen for ploughing, and larger and more fields under cultivation. While in the 1960 s, only $16 \%$ of all households owned cattle, in the 2010s, about a half of the

\footnotetext{
${ }^{12}$ NAN CAF 6.3 Reisverslag: Veeverbeteringsveldtog: OosCaprivistrook, 1972.

${ }^{13}$ NAN CAF 6.3 Reisverslag: Veeverbeteringsveldtog: Oos-

Caprivistrook, 1972, 'Die volgende koeie en verse is weens ouderdom, lae vrugbaarkeid en swak bouvorm afgekeur'.

${ }^{14}$ NAN CAF 6.3 Reisverslag: Veeverbeteringsveldtog: Oos-

Caprivistrook, 1972 'During the expedition, it came to our attention that livestock owners were fined if they inserted sticks and grassropes through their animals' noses. It is advised that this method of conduct be halted during the livestock improvement campaign as it can bring about the development of aversion amongst stock owners against livestock improvement, which can lead to them not bringing their livestock to the crush-pen'. (transl. E. Olwage).

${ }^{15}$ Goat numbers are small, and only a few households own goats. A Ministry of Lands and Resettlement Report (2015c) stated that in 2012, 136,000 cattle were counted in the Zambezi Region, but only 10,000 goats. Unlike, for example, in north-western and north-central Namibia, goats are not the key species for marketing whenever needs arise; cattle are. Goats are not considered in any of the planning documents we consulted. The Integrated Land Use Plan (2015a, 2015b) provides planning for the commercialization of cattle husbandry but does not mention goats at all.
} 


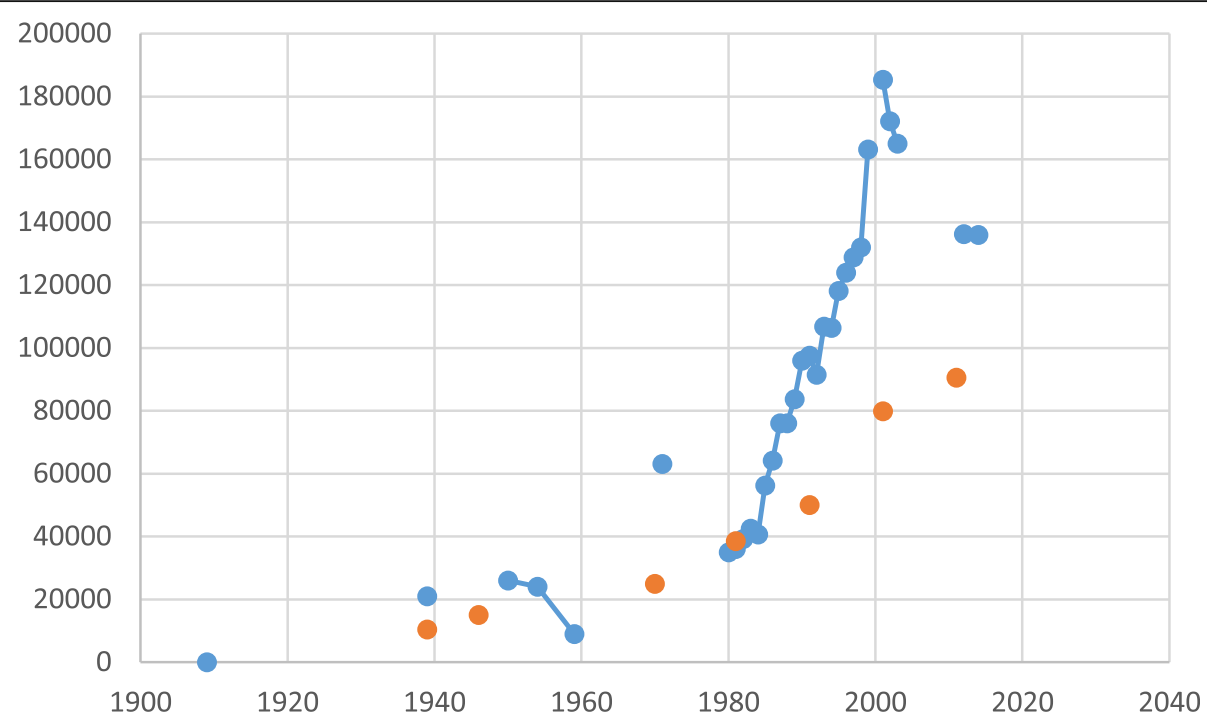

Fig. 2 The dynamics of the regional cattle herd from 1909 to 2015. Source: Veterinary Offices Windhoek, for the years 1996 to 2003 Rep. of Namibia 2004. Housing and Population Census 2001 and 2011; Kruger, C. E. 1984. History of the Caprivi Strip 1890-1984. (unpublished manuscript). NAN A0472

households possess at least a few. While ownership of cattle is still much skewed, and perhaps progressively skewed, larger numbers of households than ever before have access to cattle in the early twenty-first century. If the conservation areas of Mudumu, Nkasa Rupara, and Bwabwata as well as the state forest are subtracted from the potentially available farmland of Zambezi Region and the recent number of 140,000 heads of cattle is taken as a baseline, there are about 12.9 tropical livestock units (TLU) per square kilometre.

Figure 2 shows the increase in cattle numbers in the Caprivi/Zambezi Region over the past decades. The graph shows (blue line and dots) that substantial increases in cattle only occurred since the 1980s, reached a peak in the early 2000s, and then settled at around 140,000. The red dots show the increase in human population during the same time.

While Fig. 2 depicts the increase in cattle numbers in the entire Zambezi region over a century, figures for sub-regions or places are harder to come by. For Mudumu South, we found figures for 2017 and for 1983. These figures mirror the overall increase in cattle well: While in 1983, some 2100 heads of cattle were counted there, in 2017, their number had more than doubled to 4844 heads (see Table 1).

Within only five decades, cattle numbers increased from only a few thousand animals to more than 100,000 animals. ${ }^{16}$ These regional growth rates are also reflected on a sub-regional level. In our research region, the Kwando wetlands and adjoining savannahs, cattle numbers increased from a few hundred (at most) to several thousand. ${ }^{17}$ The next section will detail how increasing wealth in cattle spreads in the population and to what extent livestock ownership is skewed.

\section{Unequal ownership in cattle}

Van der Vegte et al. (1983:97) estimated the total number of cattle to be around 40,000 in 1983. These cattle were deemed to be owned by 8290 owners, meaning that $16 \%$ of the rural household heads owned cattle at that time. Herd sizes varied between four and 236, with $69 \%$ of the cattle herds having less than 10 animals and only $16 \%$ having more than 20 animals. The number of cattle owners has increased steadily since then. Cattle ownership spread in the wider population and more households than ever before had access to cattle. Mosimane et al. (2014:38) report on the basis of a far-flung survey covering the

\footnotetext{
${ }^{16}$ One reviewer suggested that the rapid increase in cattle could only be explained for if cattle imports from other territories were taken into account. A moderate increase of 3.5\% per annum would almost explain the entire growth rate though. The likelihood that cattle were imported from Botswana and Southern Rhodesia (Zimbabwe) and also from Angola and Zambia in the 1960s and 1970s though is high. I found no comprehensive archival evidence for such imports. In a number of interviews though, it was mentioned that people resettling from the Botswana side of the Kwando/Chobe came with cattle to the East Caprivi. In one instance, it was mentioned by a former labour migrant that he bought some few cattle in Zimbabwe (Southern Rhodesia) with his wages. In general though, the colonial administration took care to control the import of cattle especially from Zambia and Angola in order to curb cattle diseases.

${ }^{17}$ The rapid increase in cattle had negative effects on the environment, and in the mid-1990s, Mendelsohn and Roberts (1997:40) diagnose overgrazing in some areas. We will focus on the environmental effects of rapidly expanding cattle husbandry in a later contribution which we will jointly devise with ecologists from our team.
} 
Table 1 Increase in cattle numbers in Mudumu South from 1983 to 2017

\begin{tabular}{llllllll}
\hline & Lyanshulu & Mbambazi & Nongozi & Sauzuo & Sangwali & Samduno & Mudumu South total \\
\hline 2017 & 537 & 556 & 603 & 703 & 1418 & 1027 & 4844 \\
1983 & 382 & 777 & & & 941 & & 2100
\end{tabular}

Source: herd counts for 2017 from Vet. Office in Katima, for 1983, van der Vegte et al. 1983

Namibian, Botswanan, Zimbabwean, Zambian, and Angolan parts of the KAZA Park, that $26 \%$ of the sampled households in the Zambezi Region owned cattle. The report by the Ministry of Lands and Resettlement (2015a:74) states that in the Zambezi Region, $42 \%$ of all households have no cattle, while $43 \%$ have between one and 30 heads of cattle and $15 \%$ possess more than 30 head of cattle. ${ }^{18}$ These figures are corroborated by our survey, which took place in three selected villages along the Kwando River in 2018. We found that 55 out of 109 surveyed households owned cattle (50.5\%). ${ }^{19}$

Overall figures indicate a substantial increase in cattle wealth. Not only do rich cattle owners own more cattle and a larger percentage of the region's cattle herd, but so does the number of cattle-owning households increase. In a number of interviews with cattle owners in two of our three sample villages, we asked informants to rank people's wealth according to the number of cattle the household owned (Table 2). When selecting key informants, we looked for people who were themselves active in cattle husbandry and whom we thought knowledgeable about cattle ownership within the community. The rankings resulted in five to six wealth categories. We arranged these wealth categories into four strata. We also asked informants to estimate herd ownership for each wealth category they had established after the initial ranking was finished. This resulted in rough estimates on cattle ownership and on the size of the regional herd. We found that these estimates fitted well with the numbers recorded by the Veterinary Office based on actual counts during vaccination campaigns.

The estimated number of cattle from our wealthranking exercise is corroborated by recent counts by the Veterinary Office in Katima Mulilo. For Sangwali, 728 heads of cattle were counted during a vaccination campaign (owned by c. 40 owners); 690 heads of cattle were counted north of the road (owned by about 10 owners)

\footnotetext{
${ }^{18}$ Mosimane et al. (2014:38-14) report that $74 \%$ of the cattle-owning households owned one to nine cattle, $15 \% 10$ to 19 cattle, $6 \% 20$ to 29 cattle, and only $4 \%$ more than 30 cattle. In their random sample, which was spread over the entire Zambezi Region, no household owned more than 100 cattle.

${ }^{19}$ Only very few households (4.6\% or five out of 109 households) owned goats. About a third of all households owned some chickens.
}

in 2017. In Samduno, 611 animals were counted in the village and 416 north of the road. ${ }^{20}$ These figures underline the general socio-spatial pattern: many farmers in the village own few cattle per household, while north of the road, a few farmers own large herds.

While in Sangwali, 53 cattle owners were recorded, in neighbouring Samduno, 31 owners were listed (see Table 3). In both settings, about $10 \%$ of cattle-owning households were deemed to be very rich, i.e. owning cattle herds of 100 heads of cattle or more (the largest herd accounted for had about 150 animals). In contrast, $65 \%$ of all cattle owners in Sangwali and $68 \%$ in Samduno were estimated to have herds of fewer than 30 animals, and $42 \%$ in Sangwali and $36 \%$ in Samduno had cattle herds of fewer than 10 animals. Wealth in cattle was linked to a number of other social factors: all cattle owners categorized under wealth status 1 had substantial and regular salaries and/or pensions. Typically, these were pensions from the private sector or from the government but not the non-contributory old-age pensions paid to everybody in Namibia over the age of 60 . Out of 13 wealthy cattle owners (categories 1 and 2) in Sangwali, all had either salaries or pensions to draw upon. The number of pensioners amongst wealthy cattle owners was notable: out of 13 wealthy owners, five were recipients of pensions. In Samduno, out of 10 wealthy households, eight were recipients of salaries and/or pensions. This suggests that a good deal of monetary income is transferred into cattle. In fact, some wealthy herd owners admitted that they actively sought to buy cattle on a regular basis. Incomes were also invested in the drilling and equipping of private boreholes, which facilitate the husbandry of large herds significantly and open up new grazing lands. Also, wages for hired herders and fences for gardens and livestock enclosures were paid/bought with these salaries. Success was based on access to financial capital and good management decisions rather than on herdsmanship per se. The figures we obtained in Sangwali and Samduno suggest that wealth in cattle herds could only be attained through financial investments. While a good number of farmers in wealth categories 3 and 4 had no access to salaries and private sector or governmental pensions, hardly any wealthy herd owner

\footnotetext{
${ }^{20}$ The designation north/south of the road needs explanation: settlements are all situated south of the Kongola-Linyanti road or at the road. Hence, population density is high there, whereas north of the road, no permanent settlements are found and population density is very low.
} 
Table 2 Cattle owners arranged according to wealth categories resulting from a wealth-ranking exercise

\begin{tabular}{|c|c|c|c|c|c|c|c|c|}
\hline & Sangwali & Percent & $\begin{array}{l}\text { Estimated number of cattle } \\
\text { for each wealth category }\end{array}$ & $\%$ of total herd & Samduno & Percent & $\begin{array}{l}\text { Estimated number of cattle } \\
\text { for each wealth category }\end{array}$ & $\%$ of total herd \\
\hline Wealth 1 & 6 & 11 & 600 & 39 & 3 & 10 & 300 & 28 \\
\hline Wealth 2 & 7 & 13 & 350 & 23 & 7 & 23 & 350 & 33 \\
\hline Wealth 3 & 12 & 23 & 360 & 24 & 10 & 32 & 300 & 28 \\
\hline Wealth 4 & 22 & 42 & 220 & 14 & 11 & 36 & 110 & 10 \\
\hline Unranked & 6 & 11 & 0 & - & 0 & - & 0 & - \\
\hline Total & 53 & 100 & 1530 & 100 & 31 & 101 & 1060 & 99 \\
\hline
\end{tabular}

Estimated cattle per wealth category: wealth 1, 100 cattle; wealth 2, 50 cattle; wealth 3, 30 cattle; and wealth 4, 10 cattle

was without regular financial income. The results of our survey are corroborated by figures from research the administration did some 5 years earlier in Dzoti and Wuparo conservancies and neighbouring rangelands. The governmental report stated that the richest $20 \%$ of farmers owned more than half of the livestock in the area (54\%) while the poorest $20 \%$ of farmers only owned $4 \%$ of all cattle (Ministry of Lands and Resettlement 2015c).

The unequal distribution of livestock wealth directly translated into a differentiated pattern of pastoral land use. We took GPS dates of all cattle-owning households in Sangwali and Samduno. A clear spatial structure emerged. ${ }^{21}$ Rich livestock owners preferred to keep their herds north of the Kongola-Sangwali-Linyanti road in a savannah landscape immediately south of Mudumu National Park. Generally, grazing was better there, and grazing pressure was lower. Wealthy cattle owners had also drilled private boreholes during the course of the last decade. The majority of boreholes recorded were drilled in 2017 and 2018. None of the herd owners stayed permanently with these cattle herds. Most of them resided either in Sangwali or in Samduno, and only hired herders resided permanently at the cattle camp. Figure 3 shows that no farmers of categories 3 (10 to 30 cattle) and 4 (less than 10 cattle) had their cattle herded north of the road during the dry season of $2019 .^{22}$ Their cattle were herded from and around the two villages. Whereas cattle herded north of the road relied almost entirely on boreholes during the long dry season, those living in the village used the Kwando River or one of its many arms for watering.

\footnotetext{
${ }^{21}$ We thank Luca Wilke, Antonio Bollig, Fabian Fwelimbi, and Bennett K. for taking up the tiresome work to collect GPS data at each household, and Mirijam Zickel for the spatial presentation.

${ }^{22}$ The turn of wealthy cattle farmers towards these lands is also a result of the establishment of Nkasa Rupara National Park. The wetlands of the National Park became inaccessible after the conservation area was gazetted in 1990 and especially so after the refurbishment of the park in the mid-2010s. Smallholder cattle owners use wetlands along the park's boundaries.
}

These figures and spatial patterns of livestock husbandry suggest that social status and cattle ownership are closely connected. Wealth in cattle was positively commented upon, and wealthy herd owners showed pride in disclosing their wealth in cattle. During a wealth ranking, an informant exclaimed 'how can you be rich and not have cattle?' suggesting that wealth in money habitually translates into wealth in cattle. The fact that some traditional authorities did not command significant cattle numbers was commented upon frowningly-it was something that required special explanation. Wealth in cattle translates into other fields of wealth accumulation. Those wealthy herd owners who had established a cattle camp at a privately drilled borehole north of the Kongola-Sangwali-Linyanti road regularly also had huge fields close to the place they kept their cattle. In fact, many of them thought of large fields and large herds of cattle as complementary. A number of them used oxen from their herds to plough their expansive fields on which they cultivated mainly maize but also sorghum and millet. Most of the produce was for sale to mills in Katima Mulilo. They commanded three or four spans of four or six oxen, which were run by farmhands. With such accumulated draught power, even large fields could be ploughed within a short time period. Some of the wealthy herd owners also relied on tractors for ploughing their fields. They would rather sell an ox and pay for the tractor with it than count on manual ploughing. Wealthy herd owners also often owned a car. A car is almost a necessity in order to run a bush camp. Hired herders have to be supplied throughout the year, and in case the pump breaks, water has to be transported to outlying cattle posts.

We interviewed wealthy cattle farmers on the why's and how's of cattle husbandry. Several times we heard that 'cattle are like a bank account' and that it is 'the traditional way of saving'. In the previous section, we have heard that the 'traditional way of saving' is in fact not that old. Herd owners recounted how, as young labour migrants, they were advised (almost ordered) by their seniors to buy cattle 
Table 3 Ownership relations in one homestead herd in

Samduno

\begin{tabular}{|c|c|c|}
\hline $\begin{array}{l}\text { Relation to head of household } \\
\text { or owner of the enclosure }\end{array}$ & $\begin{array}{l}\text { Number } \\
\text { of cattle }\end{array}$ & Type of cattle \\
\hline $\begin{array}{l}\text { Household head and owner } \\
\text { of the enclosure }\end{array}$ & 38 & $\begin{array}{l}12 \text { oxen, } 17 \text { cows, } 3 \text { bulls, } 6 \\
\text { calves }\end{array}$ \\
\hline Son 1 & 2 & 1 ox, 1 cow \\
\hline Son 2 & 6 & 1 ox, 3 cows, 1 bull, 2 calves \\
\hline Father's brother's son & 17 & $?$ \\
\hline Wife & 15 & $?$ \\
\hline Sister 1 & 3 & 1 cow, 1 bull, 1 calf \\
\hline Sister 2 & 1 & 1 bull \\
\hline Sister 3 & 5 & 2 cows, 2 bulls, 1 calf \\
\hline Father's sister & 9 & 6 oxen, 2 cows, 1 calf \\
\hline Father's brother & 28 & 16 cows, 8 bulls, 4 calves \\
\hline \multirow[t]{2}{*}{ Mother's brother's son } & 29 & 15 cows, 10 bulls, 4 calves \\
\hline & 163 & \\
\hline
\end{tabular}

with their salaries and wages (and not to buy other commodities). ${ }^{23}$ We reckon that similar ideas may be at work as Ferguson recorded in Lesotho in the 1980s. Salaries are in fact still being transferred into cattle habitually. While cash money, according to Ferguson (1994), was rapidly spent to cater for the different needs of a large family, cattle were more secure capital for Lesotho's labour migrants. Hence, men transfer monetary income into a wealth category that is more durable. Informants reported that there is a vibrant internal cattle market and that one can always buy cattle. ${ }^{24}$ Cattle buying was depicted as easy to accomplish: the buyer just needs a copy of his ID and the original stock book, while the seller needs a letter of confirmation from the tribal council presenting him as the true owner of the head of cattle to be sold. The confirmation letter would also specify the type of cow and the number of cows being transacted. We were introduced to the practice of a WhatsApp group that was primarily

\footnotetext{
${ }^{23}$ Kangumu (2011:139-141) reports that in the 1960s and early 1970s, up to 25 to 30 migrant labourers from the East Caprivi were recruited per month to work on the Witwatersrand mines and that every labourer returned with sufficient funds to invest into assets. He concludes 'For the young men, it was adventure and prestige, a chance to acquire wealth, particularly bridewealth.'

${ }^{24}$ One reviewer justifiably inquired why the same ideas that Ferguson encountered amongst mineworkers in Lesotho are found in the Zambezi Region in Namibia. He/she alleges that long-distance migrant workers from north-eastern Namibia to the mines in South Africa 'brought back ideas about shoring up retirement wealth in cattle'. Without having asked older men who had been working in mines in South Africa exactly where their aspirations to become cattle owners came from, they of course met with migrants from Lesotho there and presumably discussed what they would do with the money they earned in order to ensure future prosperity back home.
}

geared towards facilitating cattle transactions. The seller would put a photograph of the head of cattle he wanted to sell, his desired price, and his contact details online and wait for buyers to bid. Wealthy herders-as mentioned, all equipped with good salaries-reported that there is a direct pressure to buy cattle with your first salary and to invest part of later salaries in cattle. They alleged that this would prevent salaries from being spent on consumables.

What about those herd owners residing in the village? They too kept cattle in order to have draught oxen, which could be helpful to draw a sledge and transport water, firewood, or reeds and mud for house construction from the well or from the wetlands into the village. People not owning oxen have to pay for the transport of water or reeds or for ploughing services (c. $\mathrm{N} \$ 150-200$, i.e. $€ 10-13$ per day). Smaller herds of cattle were often jointly kept with close relatives keeping their cattle in one enclosure (see Table 3). We found a number of cases where three or more herd owners kept their cattle together in one enclosure and had them jointly managed. Cattle kept within the village were rarely watered within the village due to regulation by the local khuta. Village-based cattle owners have to water their cattle out of the village at the river. Trekking cattle to the river or to one of its tributaries (molapo) is an arduous and sometimes also dangerous task as crocodiles lurk in the muddy waters in some numbers.

We did not have a conclusive look at the gendered aspects of cattle ownership. However, it is obvious that both in wealth categories 1 and 2 , in the two villages we had a closer look at, there was just one woman household head (out of 13 households). The case study below shows that women owned cattle and, like their male age-mates, transferred salaries into cattle, but generally, they owned fewer animals than their male relatives. Apparently, quite a number of the women had their cattle herded within somebody else's herd. A number of very poor households in our household sample were female-headed, and of course, none of them owned cattle. Hence, cattle ownership has a gendered dimension, privileging male household heads over female household heads, elderly men over younger men, and salary earners over unemployed people. These privileges translate into a spatial pattern which conservation planning does not take any account of. Conservancies plan space as a landscape characterized by different geo-biophysical features, degrees of biodiversity, and overall settlement and land-use patterns. They determine the zonation and land-use planning of a conservancy. The same space however is characterized by hierarchically-ordered claims to land, wealth, and unequal access to cattle (including oxen), ploughs, and tractors.

\section{Labour and the management of cattle}

Village herds are frequently amalgamated, i.e. a herd belongs to a number of owners who are habitually closely 


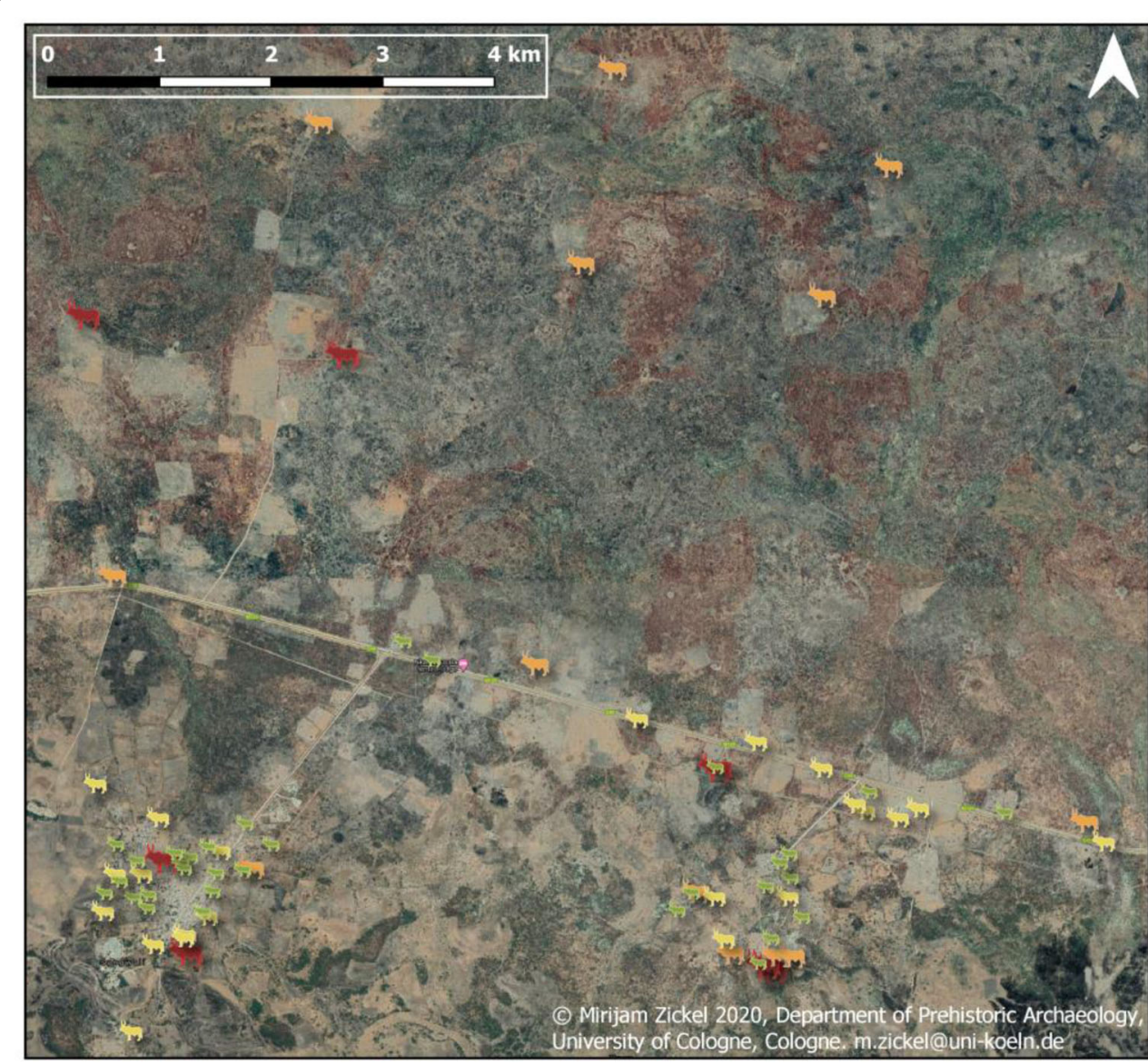

\begin{tabular}{|c|}
\hline Cattle farm size \\
ranking of \\
households in \\
Sangwali \& Samduno \\
(Zambezi, Namibia) \\
based on field data \\
from Michael Bollig \& \\
Hauke-Peter Vehrs \\
2019 \\
\hline
\end{tabular}

Fig. 3 Cattle farm size ranking of households and location of cattle herds

related. They pool their cattle, put them up in the same enclosure, and have them herded by hired shepherds they employ. However, ownership relations are hidden, and informants found it difficult to disclose such relations to outsiders. Some claimed that even within the village, nobody would really know whose cattle are in whose enclosure let alone where these cattle came from, whether they were bought from salaries or resulted from business and whether they were inherited or perhaps only loans. ${ }^{25}$

Table 3 shows cattle ownership in one village herd; the herd recorded was one of the largest village herds we found. The 160 animals herded together and kept overnight in one enclosure belonged to 11 owners. The household head who owned the enclosure owned about $25 \%$ of the cattle. There were two other owners who

\footnotetext{
${ }^{25}$ It is difficult to give clear reasons for the reluctance to talk about cattle ownership and the provenance of cattle. Our preliminary idea is that ascertaining ownership relations and ascribing property to somebody are perceived as motivating envy and other bad feelings with others. Wealth clearly has two faces; it is certainly something to be proud of but it can also endanger sociality.
}

contributed about 20\% each to the herd, and the remaining owners had smaller shares of the herd.

For all herding arrangements we received reports on, herders were paid in cash and in kind. Their salaries are very low according to Namibian standards and lay between $\mathrm{N} \$ 300$ and $\mathrm{N} \$ 800$ (18 to $50 €$ ) per month. On top of the salary, they could expect simple but sufficient food and a steady supply of water. A prior arrangement, in which herders were paid one calf per year or every third year, was no longer practised. Herd owners interviewed on that topic suggested that there was an oversupply of cattle herders from Zambia, Angola, and Zimbabwe and that it was generally easy to find herders, especially when modern means of communication or established communication channels into Zambia could be used. Some herd owners in fact went to southern Zambia by vehicle and then visited the traditional authority in one of the villages close to the international boundary. They informed him that they were in need of a herder. They claimed that within a day or two, they would recruit a sufficient number of herders. 


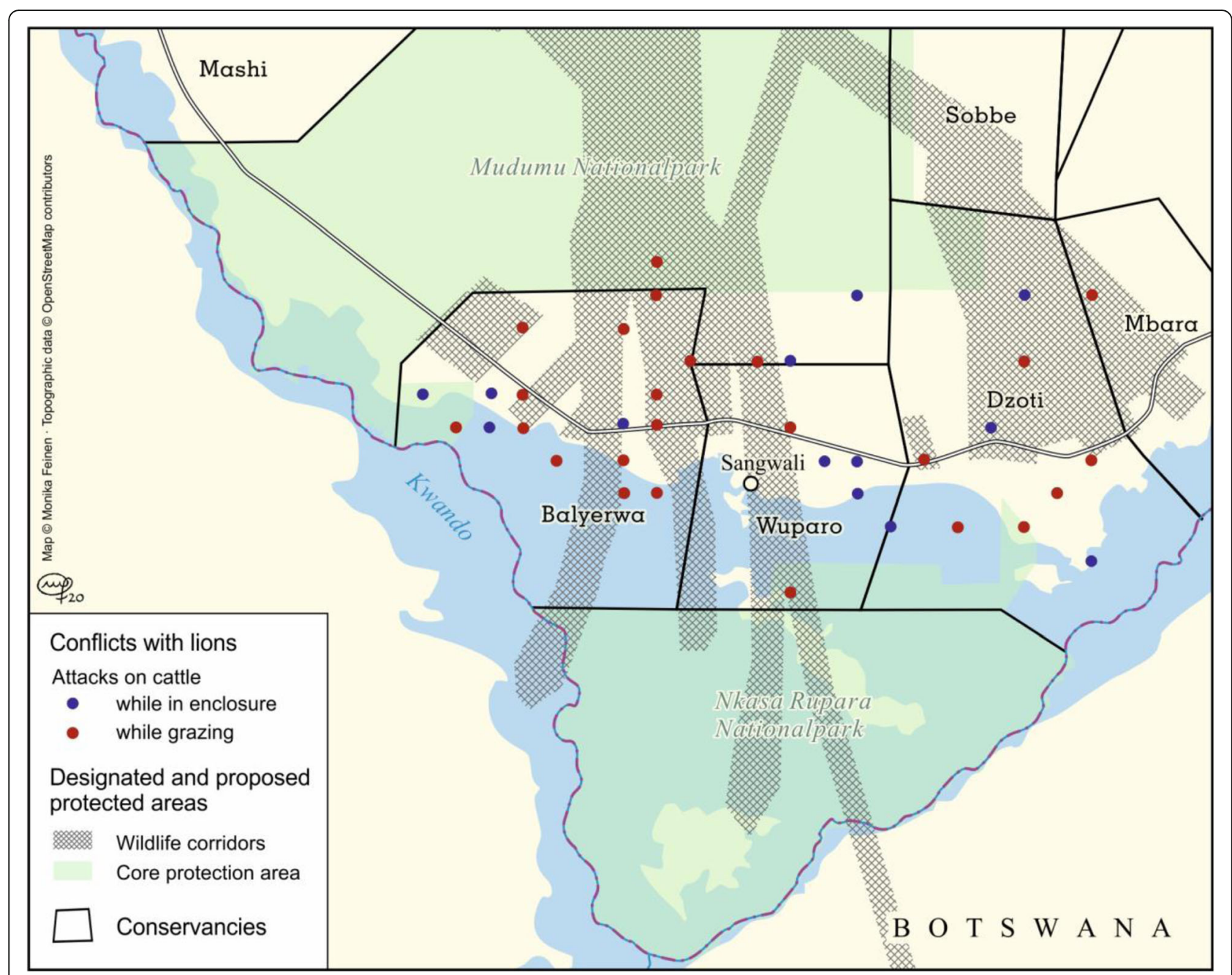

Fig. 4 Game corridors and conservation areas in Mudumu South and cattle-lion incidents

Herding of cattle became very different with the advent of privately drilled boreholes. ${ }^{26}$ While boreholes were drilled by the government already in the 1960s in some numbers, privately drilled boreholes are something new. Only since the early 2010 s did wealthy people

\footnotetext{
${ }^{26}$ We could not ascertain exactly why wealthy farmers only took to the drilling of private boreholes in the 2010s. The simultaneity of private borehole drilling and communal land reform is certainly telling. Those who invested into boreholes found it easy to claim customary land rights under the new regulations of the Communal Land Reform Act of 2002 and Regulation No. 37 of 2003 (Mendelsohn 2008). The land rights gained do not amount to a freehold land title. They rather ensure tenure security; that is, no traditional authority or any other person can easily take away that land from the rights holder. In a transitional situation marked by considerable uncertainty over communal land tenure, drilling boreholes was a meaningful step to ascertain such rights. Indeed, many informants suggested that all those who drilled boreholes also have certificates for the land around the boreholes. The intricate relation between communal land reform, tenure arrangements, and agro-pastoral change cannot be covered sufficiently in this contribution and certainly needs further research.
}

invest in boreholes, and only in the Wuparo conservancy about 10 boreholes were drilled (and possibly in Balyerwa and Dzoti another five to 10 boreholes more, so that by autumn 2019, about 15 to 20 privately boreholes had been drilled). The owners of boreholes primarily kept their own cattle at these newly formed posts, but the cattle of close patrilineal kin, often brothers, were allowed in, while other people's cattle were not allowed in. We did not observe that water was sold from these private boreholes. Informants estimated that about $\mathrm{N} \$ 60,000$ (i.e. c. $€ 4000$ ) are spent to drill a borehole. At that time, the number of cattle residing within the villages during the dry season had become a problem. During the rainy season, most cattle were habitually taken to areas north (or east) of today's Kongola-Sangwali-Linyanti road. There, they could find sufficient water for a couple of months in pools and pans. With the advent of the dry season, these pools rapidly dried up and cattle had to return to the village. They were then watered at the Kwando/Linyanti River and herded in the 
stretch of land between the village and the river. Good pastures were especially offered in the wetlands along the river from which the floods of the rainy season receded during the dry season. However, these pastures were also dangerous and contested: crocodiles frequently lurked along the channels and river banks and preyed on cattle grazing beside the shallow waters. Losses of livestock to predators were substantial. In our village survey, roughly a quarter of all households had lost livestock to predators. Losses of cattle to crocodiles were prominent, and losses of cattle to lions still fairly numerous. Hanssen and Fwelimbi (2019:35) present data on cattle-carnivore conflict in Mudumu South. There, the number of cattle killed by lions peaked in 2013, with 135 cattle killed within a year in the three conservancies of Dzoti, Wuparo, and Balyerwa. This number declined to 34 animals in 2018. In total, some 280 cattle were killed within a 5 -year period only by lions. Hanssen and Fwelimbi (2019) impressively show that most cattle were killed while grazing unattended in the savannah and that overnight kraaling in lion-proof kraals is the best insurance against predators. Such lion-proof kraals are currently given to molested communities free of charge by a local NGO in some numbers. Apparently, they contribute to a sizeable decrease in depredation. Figure 4 shows Mudumu South with game corridors and plots the cases of livestockcarnivore conflict recorded by Hanssen and Fwelimbi (2019). The close connection between game corridors running through communal lands and cattle-carnivore conflict becomes evident.

The shift of herds of wealthy herd owners to pastures north of the Kongola-Sangwali-Linyanti road made feasible by the drilling of private boreholes and triggered by the communal land reform led to a profound reorganization of regional livestock husbandry. Wealthy cattle owners established permanent cattle-cum-farm camps about 5 to $12 \mathrm{~km}$ away from the road. There, they stayed all year round on lands that had prime grazing in normal years and still sufficient grazing during the dry season. From the cattle camp, herders could move in different directions without directly entering upon heavily grazed zones. Herds from these cattle camps were often led towards the southern boundary of Mudumu National Park and apparently in some instances also crossed into the park. During the rainy season, other cattle-owning households from the village also pastured their cattle north of the road for a couple of months but soon retreated back to the village and watered cattle at the Kwando River after the dry season had set in. Of course, these village-based households had to organise themselves in light of the fact that fairly large herds of cattle had already grazed a fair amount of the territory before the village-based herds could enter there. We did not find instances where poorer cattle owners rented access to one of the private boreholes. Hence, poorer cattle-owning households had to withdraw their herds at the beginning of the dry season. Some of those poorer herd owners were convinced that the government would soon drill and equip additional boreholes in the grazing lands north of the Kongola-Sangwali-Linyanti road and thereby give them access to these prime grazing lands. In fact, the government had drilled a couple of boreholes there in 2018, but for some reasons, these boreholes had not been fitted.

\section{Consumption of cattle}

Cattle are used in many contexts. They are used as draught animals. They are (even if rarely) slaughtered, and their milk is used and in a village context even sold occasionally. ${ }^{27}$ Sometimes, they are used in social exchanges in bridewealth payments (lobola) and as cattle loans (mafisa). ${ }^{28}$

Most households make use of oxen as draught animals. If they do not own an adequate span of oxen, which at minimum consists of four trained oxen, they rent oxen spans for a day or two. Ploughs have been used in the region only since the 1960s, resulting in sizeable increases of cropped land since then. Before that, people used digging sticks and fields were much smaller. The introduction of cattle allowed fields to be much larger. In fact, one of the first items migrant workers bought with their wages were ploughs and oxen. While in the late 1950s and 1960s, ploughs had to be bought in Southern Rhodesia (now Zimbabwe), since the late 1960s ploughs could be also bought in Katima Mulilo, the capital of Zambezi Region, about $120 \mathrm{~km}$ away from our research area. We interviewed some informants in Sangwali who reported that their families only obtained ploughs in the 1980s, hinting at the fact that the coupling of cropping and cattle husbandry is rather recent. Draught oxen were not only used for ploughs but also for sledges. Due to the sandy terrain, such wooden sledges can be used well in order to transport bulky goods such as heavy containers of water, firewood, and reeds from the wetlands. Oxen should be 5 to 6 years old before they can be used as draught animals under a yoke and in a team pulling heavy weights.

Beyond contributing physical labour, cattle are also consumed by directly slaughtering them. In our survey of households in three villages in 2018, 14 household heads $(12.8 \%)$ claimed that some of their cattle had been slaughtered during the past 12 months. Eight people slaughtered cattle because an animal was sick and they

\footnotetext{
${ }^{27}$ We did not obtain any consistent data on milk production. Milk is a commodity in the village context as milk is sold bottle-wise. A 2-1 bottle sold for $\mathrm{N} \$ 20$ (c. €1.20). We do not have any information how often and in what quantities milk is sold and what percentage of milk is sold and what percentage is consumed by the household. Interestingly, informants did not mention milk prominently as a benefit of cattle husbandry.

${ }^{28}$ The fact that the terms for cattle-based bridewealth (lobola or lobolo) and for cattle loans (mafisa) are loan-words from other southern Bantu languages (Setswana and Isizulu) is indicative of the lack of cattle in such transactions in earlier times.
} 
feared that it would die or that adequate veterinary treatment would cost too much. In four instances, people slaughtered a head of cattle and sold the meat at the roadside in order to procure cash money. Two informants claimed that they slaughtered cattle to provide food for their own households. In villages like Samduno and Sangwali, habitually one or two oxen are slaughtered at the roadside and the meat is then sold over 2 days.

A major function of cattle herds is that wealth can be accumulated without the risk of being spent on minor household needs. Habitually, cattle herds do indeed work like bank accounts. While daily costs are preferably covered by small incomes, salaries, wages, and money resulting from social transfers, all costs above a few thousand Namibian dollars will be covered preferably by the prior sale of cattle. Currently, a cow sells at N\$4000 to $5000(250-310 €)$ and an ox at N\$5000 to 7000 (310 - $440 €) .{ }^{29}$ Despite the fact that cattle cannot be sold outside the region, the internal livestock market is doing well.

Within our small household survey, 11 people $(10.1 \%)$ said that they had sold cattle within the last 12 months and were willing to disclose for what purpose they had sold the animal. All cattle were sold locally. This is mandatory as the abattoir in Katima Mulilo closed down in 2016 after the entire region was quarantined due to foot and mouth disease outbreaks. Six people sold cattle to support their school-going children, paying either for fees, school uniforms, or boarding. Qualitative interviews corroborated that education is perhaps the single most important factor necessitating the sale of cattle. Carrelated problems, food, and health-related issues were only mentioned once. Some people who sold cattle mentioned that they felt pressurized to sell because the animal in question was either too old or sick. Often, cattle are sold for family-related matters and not to meet the wants and needs of the actual owner of the ox or cow. The $\mathrm{MCA}^{30}$ survey of 2014 is specific about different ways and reasons to sell cattle (MCA 2014). The data suggest that wealthier farmers sold proportionately more animals than poor farmers did. Whereas more than a half of the wealthy farmers sold cattle, less than a third of the less wealthy sold livestock. Poorer livestock farmers also earned less by selling cattle; while poorer cattle farmers selling cattle made less than $\mathrm{N} \$ 6500$ (about $400 €$ ) in cattle sales, medium wealthy farmers made $\mathrm{N} \$ 16,500$ to $\mathrm{N} \$ 35,000$ (c. $1000-2200 €$ ), and wealthy farmers even made over $\mathrm{N} \$ 57,000$ (c. $3600 €$ ) in cattle sales during the

\footnotetext{
${ }^{29}$ These prices compare fairly badly with prices paid in down-country Namibia. The fact that the entire regional herd is quarantined bears heavily on prices for cattle.

${ }^{30}$ The Millenium Challenge Account (MCA) Namibia was a major US funded programme to develop conservation and livestock husbandry in Namibia's north. It was active between 2008 and 2014.
}

reference period. The income made from cattle sales is as skewed as the ownership in cattle.

Social costs feature importantly in long-term household budgets, and here cattle are essential to comply with a number of social obligations. Cattle are needed to feed guests at funerals and at wedding parties. The major social costs however are bridewealth payments, which have increased drastically over the past five decades. Some informants stated that in the 1960s, bridewealth payments often consisted of just one cow and that in case there were no cattle owned by the family of the bridegroom, a bride service (i.e. the bridegroom works for the bride's father for some time, tills his field, builds a fence or carries reeds to his home) had been acceptable. In the 1970s, the lobola had increased from $500 \mathrm{R}$ to $1000 \mathrm{R}$, the equivalent of four cows by then. At that time, people preferred to pay lobola with money than to pay with cattle. In the 1980s, lobola increased again, and nowadays, it is habitually 15 to 30 cattle, going up to 45 cattle. Bridewealth negotiations start with the 'opening the mouth' ceremony (sikwalula mulomo). Only after N\$2000 (125€) have been paid in the sikwalula mulomo context can the true negotiations start. Then, the number of cattle is fixed, and the bridegroom's party will decide whether the payment is made in cattle or in cash. Furthermore, the sukwala mulomo ('closing the mouth') ceremony at the end of negotiations will cost $\mathrm{N} \$ 2000$ (c.125 €). If a man wants to take his wife along, he will have to pay $\mathrm{N} \$ 10,000$ (c. $625 €$ ) or 10 cattle at least; the remainder will have to be paid later. Delayed payments of up to 5 years seem to be acceptable. If a woman has been married previously, the lobola is lower.

Cattle-money equivalents in bridewealth payments sit oddly. In contrast to the current market prices, a head of cattle is the equivalent of $\mathrm{N} \$ 1000$ (c. $63 €$ ). These cattlemoney equivalents are fixed by the tribal council (khuta), and they are occasionally adjusted. In 2007, the equivalent was adjusted to $\mathrm{N} \$ 1000$ for one head of cattle, while before it was $\mathrm{N} \$ 500 /$ head of cattle for a long period of time. At independence, the equivalent had been $\mathrm{N} \$ 250 /$ head of cattle. A bridewealth payment of $\mathrm{N} \$ 45,000$ (c. $2800 €$ ) was then equivalent to 45 head of cattle. All informants claimed that this led to a situation where most people would prefer to pay their bridewealth in cash.

People not only meet social obligations with cattle, they also actively use cattle to establish social bonds. Wealthy households regularly loan cattle to other people (mafisa).

H.'s herd is rather big and counts more than 100 heads. $\mathrm{H}$. claims that many wealthy people will give mafisa cattle if their herds become too large to be managed in one place. $\mathrm{H}$. gave mafisa cattle to his brother-in-law in Lyanshulu. $\mathrm{H}$. goes there regularly to see his animals, and he also expects reports from 
there. Every third calf is given as a present to the person who holds the mafisa cow; the other calves belong to the owner. $\mathrm{H}$. thinks that cattle are an important means to build such ties of obligations. He claimed that one 'cannot do mafisa with land', but only with cattle.

Preferably, cattle loans were given within close kinship networks to consanguineal but also to affinal kin. The loans we recorded stayed within Mudumu South, which is within a short distance from the original owner. Informants were adamant that loans are secured by traditional rules: each third calf of a loaned cow belongs to the recipient of the loan; in return, he should duly report back other calves and take very good care of borrowed animals.

\section{Summary and outlook}

This overview of cattle husbandry in the south-western corner of the Zambezi Region has shown that cattle husbandry is a rather recent phenomenon. Cattle numbers grew rapidly in the entire Zambezi Region from some few hundred heads to more than 100,000 heads. In Mudumu South, cattle numbers increased from near zero to some few thousand heads of cattle within a century. Cattle ownership is strongly skewed, and a minority of cattle owners possess most of the cattle. It is especially the well-to-do salary earners or ex-earners who invest in cattle and drill boreholes away from the villages and thereby establish new patterns of land use. They have their cattle herded by farmhands, frequently of Zambian origin. Cattle are regarded as necessary repositories of wealth and a means to engage in social activities, such as bridewealth payments and cattle loans. Cattle are also indispensable as draught animals for agriculture: for ploughs and sledges (which transport, for example, water and building material), a number of oxen are needed, and the larger the homestead, the more draught oxen are necessary. The wealthy regard cattle herds as a major asset to accumulate and safeguard wealth.

Cattle husbandry and changing land-use patterns directly impact official and community-based conservation strategies (and vice versa). There is a need to integrate both land-use strategies. Both conservation and livestock husbandry depend on open spaces, mobility, and institutional arrangements governing common-pool resources, savannah landscapes, and water sources (see Western et al. 2020 for a similar context along the Kenyan/Tanzanian boundary). The establishment of exclusive zones and corridors for wildlife or for cattle seems to run counter to the need for mobility and flexible land-use arrangements. Western et al. (2020) advertise an insideout' approach which seeks to integrate biodiversity conservation and pastoral land use. The human-centred approach to ensure spatial connectivity is based on multi- level agreements and co-management efforts at all levels. This suggests for the Mudumu South conservation landscape that the planning for national parks and conservancies has to be co-managed with the aspirations and practices of cattle owners. Long-term viability of refaunation and biodiversity may be strengthened through technological innovations (e.g. enforced cattle enclosures) to lower human-wildlife conflict, innovative distributive mechanisms relating to benefits accruing from conservation (both from conservancies and national parks), and governance approaches preventing a dismantling of the commons and advocating a joined management of natural resources.

\section{Abbreviations}

NACSO: Namibian Association of Community Based Natural Resource Management Support Organisations; NAN: National Archives of Namibia; N\$: Namibia dollar

\section{Acknowledgements}

We thank farmers in Zambezi Region and specifically in Mudumu South as well as officials in the Department of Veterinary Services in Katima Mulilo and staff of the conservancies in Wuparo, Balyerwa, and Dzoti for cooperation and for their collaboration.

\section{Authors' contributions}

Both authors contributed to the conception, design, analysis, and writing up of this research. Both authors read and approved the final manuscript.

\section{Funding}

This research has been funded by the German Research Council within the context of the Collaborative Research Centre 228 Future Rural Africa. We thank the Government of Namibia for respective research permits and our colleagues at the University of Namibia (UNAM) both in Windhoek and Katima Mulilo for intensive discussions on the subject. Research has been reviewed by an Ethics Committee at the University of Cologne in 2018.

\section{Availability of data and materials}

Not applicable.

\section{Ethics approval and consent to participate}

This research received an ethics approval from the Ethical Committee of the Faculty of Medicine at the University of Cologne. Prior to interviews, all interviewees were informed about the purposes of the research and how the results would be used and gave their consent to participate.

Consent for publication

Not applicable.

\section{Competing interests}

The authors declare that they have no competing interests.

\section{Author details}

${ }^{1}$ Institute for Social and Cultural Anthropology, University of Cologne, Cologne, Germany. ${ }^{2}$ Global South Studies Centre Cologne, University of Cologne, Cologne, Germany.

Received: 16 April 2020 Accepted: 16 June 2020

Published online: 28 September 2020

\section{References}

Bolaane, Maitseo M.M. 2013. Chiefs, hunters and san in the creation of the Moremi Game Reserve, Okavango Delta: Multiracial interactions and initiatives, 19561979 (Senri Ethnological Studies 83). Suita: National Museum of Ethnology.

Bollig, M. 2020. Shaping the African savannah. Cambridge: Cambridge University Press. DIVA-GIS. 2018 Free spatial data. Electronic document, http://www.diva-gis.org/ gdata. Accessed 19 Sept 2018. 
Environmental Information Service Namibia, 2018: Core conservation areas GIS layers. Online available: http://www.the-eis.com/searchresults.php?action= coninfo. Accesssed 31 Oct 2018.

Ferguson, J. 1994. Anti-politics machine: Development, depoliticization and bureaucratic power in Lesotho. Cambridge: Cambridge UP.

Hanssen, L. \& H. Fwelimbi 2019. Human-lion conflict mitigation in the Zambezi Region Namibia. Report March 2019. www.facebook.com/kwandocarnivoreprojecrt

Kalvelage, L., J. Revilla-Diez, M. Bollig. (n.d.) How much remains? Local value capture from tourism in Zambezi, Namibia. Tourism Geography (under review).

Kangumu, B. 2011. Contesting Caprivi. A history of colonial isolation and regional nationalism in Namibia. Basel Namibia Studies 10. Basel: Basler Afrika Bibliographien.

Kurugundla, C.N., P.M. Kgori, and N. Moleele. 2012. Management of tsetse fly using insecticides in northern Botswana. IntechOpen https://www.intechopen.com/ citation-pdf-url/28274

Lane, P. 2013. Trajectories to pastoralism in northern and Central Kenya: An overview of the archaeological and environmental evidence. In Pastoralism in Africa: Past, present and future, ed. M. Bollig, M. Schnegg, and Hans-Peter Wotzka, 105-143. Oxford: Berghahn.

Lenggenhager, Luregn. 2018. Ruling nature, controlling people: Nature conservation, development and war in north-eastern Namibia since the 1920s. Oxford: Basler Afrika Bibliographien.

Lubilo, R. 2018. The enactment of 'community' in community based natural resource management in the Zambezi Region. Namibia: PhD Dept. of Rural Development Sociology, Wageningen University.

MapCruzin 2018: Free GIS shapefiles, software, resources and geography maps. Online available: https://mapcruzin.com/ (last access 01 Nov 2018). ArcGIS shapefiles are derived from www.OpenStreetMap.org

Mendelsohn, J. 2008. Customary and legislative aspects of land registration and management on communal land in Namibia. Windhoek: Report prepared for the Ministry of Land \& Resettlement and the Rural Poverty Reduction Programme of the European Union.

Mendelsohn, J., and C. Roberts. 1997. An environmental profile and atlas of Caprivi. Windhoek: Directorate of Environmental Affairs Ministry of Lands and Resettlement 2015a. Integrated Land Use Pan for the Zambezi Region (Vol. 2). Windhoek

Millenium Challenge Account (MCA) -Namibia. 2014. Evaluation of MCA Namibia's livestock support activity. Windhoek: Manuscript.

Ministry of Lands and Resettlement. 2015a. Zambezi integrated regional land use plan. Windhoek: Southern African Institute for Environmental Assessment.

Ministry of Lands and Resettlement. 2015c. Strategic environmental assessment (SEA) of the Zambezi integrated regional land use plan. Windhoek: Southern African Institute for Environmental Assessment.

Moore, L. 2010. Conservation heroes versus environmental villains. Perceiving elephants in the Caprivi Strip. Human Ecology 38: 19-29.

Morton, Barry. 1996. A social and economic history of a Southern African native reserve: Ngamiland 1890-1966: (PhD Dissertation, Indiana University) (Accessed 13 Feb 2020)

Mosimane, A., S. Lendelvo, S. Glatz-Jorde, M. Huber, and H. Kirchmeir. 2014 Livelihood baseline survey report for the Kavango Zambezi Transfrontier Conservation Area (KAZA TFCA). Windhoek: University of Namibia. Multidisciplinary Resource Centre.

Naidoo, R., M.J. Chase, P. Beytell, P. du Preez, K. Landen, G. Stuart-Hill, and R. Taylor. 2016b. A newly discovered wildlife migration in Namibia and Botswana is the longest in Africa. Oryx 50: 138-146.

Naidoo, R., P. du Preez, G. Stuart-Hill, M. Hago, and M. Wegmann. 2012. Home on the range: factors explaining partial migration of African Buffalo in a tropical environment. Plos One 7 (5): e 36527.

Naidoo, R., J.W. Kilian, P. du Preez, P. Beytell, O. Aschenborn, R.D. Taylor, and G. Stuart-Hill. 2018. Evaluating the effectiveness of local- and regional-scale wildlife corridors using quantitative metrics of functional connectivity. Biological Conservation 217: 96-103.

Naidoo, R., Ch. Weaver, R. Diggle, G. Matongo, G. Stuart-Hill, and Ch. Thouless. 2016a. Complementary benefits of tourism and hunting to communal conservancies in Namibia. Conservation Biology 30: 628-638.

Peregrine, A.S., and M. Mamman. 1993. Pharmacology of diminazene: A review. Acta Tropica 54: 185-123.

Pretorius, J. 1975. The few of the eastern Caprivi Zipfel. A study of their historical and geographical background, tribal structure and legal system, with special reference to the few family law and succession. Stellenbosch: Master Thesis. University of Stellenbosch.

Protected Planet 2018: Botswana, Africa. Online available: https://www. protectedplanet.net/country/BW. Accessed 1 Nov 2018.

QGIS Development Team. 2018 QGIS Geographic Information System. http://qgis. osgeo.org.

Republic of Namibia. 2004. Report on the annual agricultural surveys 1996-2003. Windhoek: Central Bureau of Statistics.

Seiner, Franz. 1909a. Die wirtschaftsgeographischen und politischen Verhältnisse des Caprivizipfels. Berlin: Wilhelm Süsserott.

Seiner, Franz. 1909b. Ergebnisse einer Bereisung des Gebiets zwischen Okawango und Sambesi (Caprivi-Zipfel) in den Jahren 1905 und 1906. Mitteilungen aus den deutschen Schutzgebieten 21, 225-316.

Silva, J.A., and A. Mosimane. 2014. "How could I live here and not be a member?": Economic versus social drivers of participation in Namibian conservation programs. Human Ecology 42 (2): 183-197.

Stoldt, M., T. Göttert, C. Mann, et al. 2020. Transfrontier conservation areas and human-wildlife conflict: The case of the Namibian component of the Kavango-Zambezi (KAZA) TFCA. Scientific Reports 10: 7964. https://doi.org/10. 1038/s41598-020-64537-9.

Streitwolf, Kurt. 1911. Der Caprivizipfel. Berlin: Wilhelm Süsserott.

Taylor, J. 2012. Naming the land. San identity and community conservation in Namibia's West Caprivi. Vol. 12. Basel: Basel Namibia Studies Series.

Van der Vegte, C.W. Forster, and W.R. Forse. 1983. Eastern Caprivi Regional Development Strategy.

Western, D., P. Tyrell, P. Brehony, S. Russell, G. Western, and J. Kamanga. 2020 Conservation from inside-out: Winning space a place for wildlife in working landscapes. People and Nature 2020 (2): 279-279. https://doi.org/10.1002/ pan3.10077.

\section{Publisher's Note}

Springer Nature remains neutral with regard to jurisdictional claims in published maps and institutional affiliations.

\section{Submit your manuscript to a SpringerOpen ${ }^{\circ}$ journal and benefit from:}

- Convenient online submission

- Rigorous peer review

- Open access: articles freely available online

High visibility within the field

- Retaining the copyright to your article

Submit your next manuscript at $>$ springeropen.com 